\title{
Specification a model for study of Internet reliability
}

\author{
Especificação de um modelo para estudo da \\ confiabilidade da Internet
}

\section{Especificación de un modelo para estudiar la fiabilidad de Internet}

\author{
Javier Carreón GUILLÉN ${ }^{1}$ \\ José Marcos Bustos AGUAYO ${ }^{2}$ \\ Jorge Hernandez VALDÉS ${ }^{3}$ \\ Margarita Juárez NÁJERA 4 \\ Cruz García LIRIOS 5
}

\section{Correspondência}

Autor para correspondência: Cruz García Lirios

Vinculação: Unidad Académica Profesional Huehuetoca, Universidad Autónoma del Estado de México

Telefone: +525512293631

E-mail: cgarcial213@profesor.uaemex.mx

ORCID: http://orcid.org/0000-0002-9364-6796

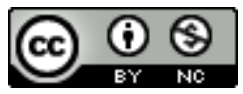

Submetido em: 12/12/2019

Aceito em: 23/05/2020

Publicado em: 10/06/2020

\footnotetext{
${ }^{1}$ Doctor en Administración, Profesor de Carrera Titular "C", Escuela Nacional de Trabajo Social, Universidad Nacional Autónoma de México: javierg@unam.mx

2 Profesor de Carrera Titular "C", Facultad de Estudios Superiores Zaragoza, Universidad Nacional Autónoma de México: marcos.bustos@unam.mx

3 Doctor en Trabajo Social, Profesor de Carrera Titular "C", Escuela Nacional de Trabajo Social, Universidad Nacional Autónoma de México: jorheval@unam.mx

4 Profesora Investigadora, Universidad Autónoma Metropolitana, Unidad

Azcapotzalco: mjn@azc.uam.mx

${ }^{5}$ Profesor de Asignatura, Unidad Académica Profesional Huehuetoca, Universidad Autónoma del Estado de México: cgarcial213@profesor.uaemex.mx
} 


\section{ABSTRACT}

Gross mode, social reliability emerges after an agenda is established with issues focused on political corruption that, far from directing a debate and public consensus, generate negative emotions that result in social despair, a suitable setting for the propaganda of the rectory the authoritarian state. The objective of the present work is to establish a model for the study of the phenomenon in question. A documentary study was carried out with a non-probabilistic selection of sources indexed to national repositories, considering the year of publication in the period 2000 to 2019, as well as the inclusion of concepts such as "reliability", " millennials ", "Internet users". The results suggest the non-rejection of the null hypothesis regarding the significant differences between the findings reported in the literature regarding the responses of respondents about reliability on the Internet. The specification of the model will allow to anticipate scenarios of internet use. There are lines of research regarding the extension of the model and its contrast in electoral processes.

Keywords - Agenda, reliability, millennials, netizens model

\section{RESUMO}

De modo geral, a confiabilidade social surge após o estabelecimento de uma agenda com questões focadas na corrupção política que, longe de direcionar um debate e um consenso público, geram emoções negativas que resultam em desespero social, cenário adequado para a propaganda da reitoria autoritária Estado. O objetivo do presente trabalho é estabelecer um modelo para o estudo do fenômeno em questão. Foi realizado um estudo documental com uma seleção não probabilística de fontes indexadas aos repositórios nacionais, considerando o ano de publicação no período de 2000 a 2019, bem como a inclusão de conceitos como "confiabilidade", "millennials", "Internet usuários". Os resultados sugerem a não rejeição da hipótese nula em relação às diferenças significativas entre os achados relatados na literatura em relação às respostas dos entrevistados sobre confiabilidade na Internet. A especificação do modelo permitirá antecipar cenários de uso da Internet. Existem linhas de pesquisa sobre a extensão do modelo e seu contraste nos processos eleitorais.

Palavras-chave - Agenda, confiabilidade, geração do milênio, modelo de internautas

\section{RESUMEN}

En general, la confiabilidad social surge después del establecimiento de una agenda con temas centrados en la corrupción política que, lejos de dirigir un debate y consenso público, genera emociones negativas que resultan en desesperación social, un escenario apropiado para la propaganda del rector. Estado autoritario. El objetivo del presente trabajo es establecer un modelo para el estudio del fenómeno en cuestión. Se realizó un estudio documental con una selección no probabilística de fuentes indexadas a repositorios nacionales, considerando el año de publicación en el período 2000 a 2019, así como la inclusión de conceptos como "confiabilidad", "millennials", "usuarios de Internet". Los resultados sugieren el no rechazo de la hipótesis nula en relación con las diferencias significativas entre los hallazgos reportados en la literatura en relación con las respuestas de los encuestados sobre la confiabilidad en Internet. La especificación del modelo permitirá anticipar escenarios de uso de Internet. Hay líneas de investigación sobre la extensión de modelo y su contraste en los procesos electorales.

Palabras clave: agenda, confiabilidad, generación del milenio, modelo de Internet 


\section{INTRODUÇÃO}

Social reliability, for the purposes of this paper, alludes to a system of conferences, perceptions and dispositions of trust, empathy and commitment around a public service such as water supply, repair of leaks or the desol sewers that, due to their degree of need and social expectation, suppose a dependency of the citizenship on the State (GARCÍA, 2019).

In such a scenario, social reliability has been a determinant of the electoral preference, the intention to vote and the effective suffrage of the electorate that establishes a pragmatic relationship with its authorities and possible local representatives as federal (ALDANA; ESPINOZA; HERNÁNDEZ; GARCÍA, 2018).

But social reliability by their degree of economic dependence of civil society towards their rulers, has been recently observed in communities and youth sectors with access to information such as the case of Internet millennials (VILLEGAS, et al., 2018).That is, if social reliability consists of a relationship of exchange of political support for an economic or in-kind amount during federal or local political contests, then access to information should limit and inhibit social reliability (VILLEGAS et al., 2019).

In the case of millennials virtual communities such a phenomenon would not exist given the production and dissemination of information against the political class or the denunciation of corruption cases involving officials (GARCIA; ESPINOZA; CARREÓN, 2018). 
Social reliability would be mediated at least by the dynamics of digital networks such as Facebook, Twitter, Instagram, WhatsApp or Snap Chat, the production and content against the political contest, parties or candidates.

In this sense, a review of the state that keeps the social reliability, mediated by electronic technologies, devices and networks will allow to notice the degree of support that a system, party or candidate could have as long as this social reliability is not inhibited by the intensive use of digital networks.

Precisely, the objective of this work is to establish a model for the study of social reliability in electronic networks. The project is part of the discipline of Social Work, an area of documentary studies, but includes terminology of cyberpsychology, the sociology of information and economics.

\section{STRATEGIC INFORMATION SOCIETY}

The information society understood as the processing of data in view of more potential than real users, brought with it the security in the use of the devices that were soon revealed as market instruments (GARCÍA, 2020). In that tenor, users were exposed to the usurpation of their identity. Thus, public institutions were violated as repositories of personal data. Faced with this scenario, Internet users developed their data protection skills from a computer defense to the construction of an identity based on new rules of communication, interaction and entertainment. 
The information society built a system of computer and programmatic symbols, meanings and meanings that delineated the relationships between institutions and organizations in the management, production and transfer of knowledge (BERMÚDEZ, 2019). The formation of human capital as an intangible asset of organizations, as well as intellectual talent, consolidated the strategic alliance between universities and companies. The flexibility of the labor market consisting in the intensive use of technologies, devices and information and communication networks radicalized academic and labor training to such a point of dependence.

This is how knowledge management was developed with the use of information decoding technologies and data mining for the timely analysis of opportunities against objectives, tasks and goals established in the academy's alliance with the local market (CARREÓN, 2019). Therefore, the intensive use of electronic technologies, devices and networks is a central phenomenon in the understanding and explanation of contemporary society considering its close relationship with generations dedicated to data processing and mass consumption of information.

Consequently, the information society stands out; 1) confidence in technology, networks and electronic devices preferably data processors; 2) reliability around distance, virtual or digitized relationships between users; 3 ) loyalty to social networks such as Facebook, twitter, YouTube, WhatsApp, Instagram, SnapChat or Tinder.

\section{THEORY OF RELIABILITY INTERNAUT}


The theoretical frameworks that explain social reliability are: 1) theory of rational choice, 2) theory of human capital and 3 ) theory of the emerging agenda.

The theory of rational choice in explaining the differences between expected costs and benefits opens the discussion around the distrust or reliability of a civil sector to an authority, official, potential candidate or representative.

In this sense, rational choice precedes social reliability if the expected benefits clearly exceed the expected costs (CARREÓN; GARCÍA, 2013).

However, the rational choice to be determined by the degree of access and capacity for information processing, estimation of possible losses and benefits, linked to political support, is determined not only by the access to electoral propaganda, but by the ability to of discernment of the electorate to whom the promotion is directed (CARREÓN; DE LA CRUZ; MAGANDA, 2015) .

In the case of millennials, social sector distinguished by their ability to access and information processing, social reliability seems to be reduced to a minimum phenomenon as in the case of posters or allusive videos ridiculing a party or political candidate (CARREÓN; GARCÍA; HERNÁNDEZ, 2014).

In this way, the theory of rational choice only warns that the access and processing of political proselytism can be effective if it is intensified in social networks in such a way that the benefits begin to overcome the costs and ridicule that Internet 
users spread between they with respect to a political contest (CARREÓN; HERNANDEZ; BUSTOS; GARCÍA, 2017).

It will be the theory of human capital that will come to clarify the panorama of political promotion in digital networks by showing that the capabilities of Internet users are determinants of electoral propaganda in digital networks.

This is because virtual communities develop computational skills based on their degree of affinity.

In this sense, Internet users themselves are the promoters of an electoral preference, voting intention or effective suffrage among their contacts and through strategies of espionage (stalking), ridicule (bullying) or discrediting (trolling) towards candidates or parties (GARCÍA, 2014).

Social reliability, according to the approach of human capital, is an effect of computational skills that specialize in discrediting political parties and candidates, establishing an agenda of aggression and violence against the political class, officials or local authorities, to the instead, they activate reactions by supporting emerging parties or candidates with whom Internet users feel more identified by their image as critics of the government system or apolitical (GARCÍA, 2015).

Precisely, the computational skills that generate ideas contrary to a political system, government regime or state form, suppose strategies of promotion of parties and emerging candidates that benefit the parties and hegemonic candidates in the electoral contests. 
This is so because the Internet electorate, in relation to other voters who do not have access to the Internet or produce or disseminate information on digital networks, is susceptible to seeking alternatives of information, preference and political choice (GARCÍA et al., 2015).

The theory of the emerging agenda to explain that traditional media will disseminate information that occurs in digital networks, is a scenario of opportunities and capabilities of processing and generation of information in which the differences between Internet users and non-Internet users they exacerbate, open the discussion around an emerging agenda (GARCÍA et al., 2016).

In this way, social reliability is part of that emerging agenda in which uncertainty prevails, discredit, distrust and discredit of political and social actors, fostering a collective fear that borders the electorate to another for the party that knows how it will govern in the future (CARREÓN; HERNANDEZ; BUSTOS; GARCÍA, 2017).

In short, social reliability is the result of a process of rational choice, human capital and emerging agenda, which reflects a risk scenario and threatens the economic, political, social and emotional stability of the electorate, favoring an electoral preference, intention of vote and suffrage in favor of the more traditional party that by its degree of authoritarianism, legitimizes the use of violence and repression in dissidents whose Internet skills contribute to the climate of anxiety, despair and fear in the electoral contests. 


\section{STUDIES OF INTERNET RELIABILITY}

Studies of social reliability have focused their interest in the demonstration of indicators of the phenomenon in order to establish a public agenda focused on helplessness, hyperopia or detachment to a town governed with authoritarianism, but susceptible to greater political corruption (CARREÓN; GARCÍA; HERNÁNDEZ, 2014).

Some works deal with asymmetries in governments and governed by social reliability because, while the former show distrust in international governance guidelines such as transparency and accountability, the latter rather rely on bribing political officials (CARREÓN; DE LA CRUZ; MAGANDA, 2015).

The works of social reliability also distinguish it against adherence and political identity. While social reliability is the result of a latent threat of corruption and ungovernability, political adherence implies a formation or politicization of civil society in the face of a common problem and political identity refers to a civic formation materialized in civil, environmental or community participation (CARREÓN; GARCÍA; HERNÁNDEZ, 2014).

However, studies of social reliability have also anticipated scenarios of conflict and social change, such as public services in general and the electricity or water supply system in particular.

In such examples, studies of social reliability have shown that this is a determinant of voting intentions or suffrage in favor of candidates and parties proposing the regularization of the supply system, the freezing of tariffs or the offer of subsidies as 
condonations for the extemporaneous payment (CARREÓN; GARCÍA, 2013).

In relation to other variables such as quality of life and subjective well-being, social reliability is associated with those groups that develop life satisfaction such as self-management of electricity or water, as well as expectations and positive and significant experiences of the user towards the public services (CARREÓN; GARCÍA; HERNÁNDEZ, 2014).

This is how social reliability is a mediating factor in the effects of government policies, programs and strategies rather than the result of institutional action or the quality of bureaucratic attention.

That is, social reliability seems to be more a predisposition to the trust forced by the supposed protection or certainty of a regime compared to the uncertainty and potential corruption of emerging parties and candidates (GARCÍA et al., 2015).

However, studies of social reliability have not reliably explained the condition of access, processing and dissemination of information with respect to groups that are distinguished by their Internet skills with respect to other sectors of civil society (CARREÓN; HERNADEZ; BUSTOS; GARCÍA, 2017).

In the case of millennials, its degree of access to information, horizontal communication, bilateral motivation and shared decision-making, it seems to show that inside he groups inhibit social reliability, but at the same time, activate and diversify in the other sectors of the population (GARCÍA et al., 2016). 
Therefore, it is necessary to formulate a model that includes axes, trajectories and relationships among the factors used in the literature consulted in order to explain and anticipate social conflict or reliability scenarios, as well as future social changes or exacerbation of local political authoritarianism among the social and governmental actors.

\section{SPECIFICATION OF AN INTERNET USE MODEL}

A model is a representation of the relationships between the factors that explain a phenomenon with what social reliability is and in relation to other processes such as agenda setting, rational choice, human capital, quality of life, subjective well- being.

The sociopolitical reliability, indicated by discredit, stalking, ridicule or harassment, is a scenario prone to the propaganda of the rectory of the State in private affairs, defender and protector of security in digital networks in the face of cases of theft of identity or violation of privacy.

More specifically, social reliability would be indicated by the degree of discrediting of the government in turn and the possibility of a political change with the promotion of a party or candidate close to Internet users, their needs for access, privacy and identity, as well as their expectations of technological advances.

However, such sociopolitical reliability could not emerge if there were no promoters who, without intending to do so, disseminate fear in the Internet users, generating an anxiety and 
defense against any cyber-attack, hacking their information, theft or impersonation of their identity, but essentially the feeling of being stalked by strangers.

In this way, socio-political reliability would also be indicated by the level of discredit of the authorities, but at the same time the need to hold someone accountable and entrust the monitoring of digital networks.

\section{METHOD}

A documentary, study was carried out with a selection of sources indexed to leading repositories in Mexico such as Copernicus,

Dialnet, Ebsco, Latindex, Publindex, Scielo and Redalyc, considering the period of publication of 2000-2019

The selected information was processed following the Delphi technique, which consists in comparing and integrating the data in order to propose new explicit concepts of the phenomenon in a model of axes and trajectories of relations between the factors in question.

A cross-sectional, exploratory and exploratory study of the dimensions of Internet reliability was carried out, for which a non-probabilistic sample of 340 students was surveyed ( $M=$ 22.1 and $S D=2.1$ years, $M=6 \cdot 897.21$ and $D E=456.34$ monthly income), participants of the programs of access to scientific information. The Internaut Reliability Scale was used, which includes two dimensions; aversion to the optimization of retrospective resources and propensity to innovation of 
prospective processes. Each item is answered with one of five options ranging from $0=$ "not likely" to 5 = "quite likely". The information was processed in the statistical package for social sciences version 24.0 in order to establish normality, adequacy, sphericity, validity, correlation and adjustment.

\section{RESULTS}

The distribution of the responses to the items that correspond to the Internet User Reliability Scale, as well as the parameters of validity and internal consistency which exceeded the minimum necessary.

In order to establish the trajectories of relations between the two factors and indicators, a model of equations was estimated in order to observe the beta weights between the variables and the adjustment of the theoretical model with respect to the empirical model

The parameters of adjustment and residuals $\left[\mathrm{X}^{2}=13,24\right.$ (23df) p ,05; GFI = ,990; CFI = ,995; RMSEA $=$,008] suggest the non-rejection of the null hypothesis relative to the significant differences between the theoretical model and the empirical model.

\section{DISCUSSION}

The contribution of this work to the state of the matter lies in the establishment of a model for the study of social reliability, indicated by the levels of harassment or discredit of authority, 
but not as an alternative to the political system but as a hopelessness.

However, the selection of the sample of informative sources, as well as the processing technique limits the empirical test of the model to a local context, suggesting a selection and analysis of more sophisticated content such as could be done in international repositories.

We recommend the use of repositories such as Copernicus, Ebsco, Scopus and WoS, as well as the data mining technique in order to extend the limits of the model and contrast its axes as explanatory trajectories among the factors used in the literature consulted.

In the same way, the extension of the model will allow to anticipate scenarios of conflicts and changes between political and social actors since, the literature reviewed has shown a positive and significant association between identity and reliability as determinants of quality of life and well-being subjective.

It is recommended to include the factors in question in order to be able to contrast the model in different contexts and samples governed in political systems or State regimes different from participative democracies and Internet users.

The model that would explain the reliability towards the Internet as a scenario of discredit and harassment, would include two routes: 1) A path that goes from distrust to governments and culminates in the prevention of risks from the usefulness of technologies, devices and networks social. This is the case of the 
emergence of pages, groups and software dedicated to the identification, monitoring and profiling of users such as Amazon. 2) A trajectory that goes from distrust towards technology, devices and networks to the construction of a public agenda of political and social prosecution. This is the case of the use that fundamentalist and radical groups give the Internet as an instrument of dogmatization, or criminal groups dedicated to extortion, identity theft or indoctrination.

\section{CONCLUSION}

The aim of the present work to the state of the question lies in the exploration of Internet reliability, but the design of the research limited the results to the research scenario, suggesting the extension of the work to the dimensions related to prospective optimization and innovation retrospective to close the cycle of reliability that literature poses as fundamental in the understanding of cooperative, competitive and collaborative relationships.

The discussion of the central categories for the study of the reliability of the Internet will allow us to move towards the systematic observation of a way of participation consisting in the construction of an Internet user agenda.

In this scenario of intensive use of technologies, devices and digital networks, the emergence of reliability implies two preventive and reactive trajectories in the face of the onslaught of organized crime and the resurgence of political authoritarianism. 
Thus, the information society and with it the emergence of the Internet and user groups are a response to the intervention of the State and the implementation of crime that result in computer security.

Groups organized in Internet networks seem to build strategies for resource optimization and process innovation, transforming academic and labor training into a liberation and informative cooperation.

In relation to the Internet Reliability Scale, the measurement of civil confidence with respect to security in the use of information technologies, devices and networks can be diversified towards other security scenarios in the monitoring of the territory, migration, prevention of crime, intellectual conflicts or personal well-being.

Regarding the proposed model and in comparison, to other alternatives, this work incorporates the security dimension in information technology, devices and networks, highlighting two theoretical axes that can be contrasted in insecurity scenarios such as identity theft, extortion or frauds

\section{REFERENCES}

ALDANA, W. I.; ESPINOZA, F.; HERNÁNDEZ, J.; GARCÍA, $C$. Model specified for the study of collaboration in a knowledge producing university. Civilize, v. 18, n. 35, p. 1-19, 2018.

BERMÚDEZ, G. Meta-Analitycal validity of the social entrepreneurship inventory A ramdom effects sizes. Global Journal of Management and Business Research, v. 20, n. 1, p. 14-19, 2019. 
CARREÓN, J. Models of fixed effects of diffuse variables in the formation of intellectual capital. International Journal of Engineering Research and Development, v. 15, n. 19, p. 17, 2019.

CARREÓN, J.; GARCÍA, C. Theory of public safety and perception of crime. Margin, v. 71, p. 1-16, 2013.

CARREÓN, J.; DE LA CRUZ, P.; MAGANDA, M. The administration of social fears. Contrast in a model of perception of security in Mexico. Ehquity, v. 4, p. 31-60, 2015.

CARREÓN, J., GARCÍA, C.; HERNÁNDEZ, J. Emotions and distrust towards the authorities. Turns, v. 16, n. 1, p. 163$184,2014$.

CARREÓN, J.; HERNÁNDEZ, J.; BUSTOS, J. M. ; GARCÍA, C. Business promotion policies and their effects on the perception of risks in coffee growers in Xilitla, San Luis Potosí, central Mexico. Poiesis, v. 32, p. 33-54, 2017.

GARCÍA, C. Specification of social entrepreneurship model. Reason \& Word, v. 18, n. 88, p. 1-41, 2014.

GARCÍA, C. The sociopolitical legitimacy of the public security administration in Xilitla, San Luis Potosí, Mexico. Administrative Investigation, v. 115 , n. 44, p. 2440, 2015.

GARCIA, C. Inteligencias y sabidurías organizacionales: Redes de conocimiento en torno al aprendizaje de la complejidad.

Psicogente, v. 22, n. 41, p. 1-28, 2019.

GARCÍA, C. Organizational intelligences and wisdoms:

Knowledge networks around complexity. Psycho, v. 22, n. 41, p. 1-28, 2019. 
GARCÍA, C. Specification a model of latest organizational. Journal of Geography, Environmental and Earth Science International, v. 10, p. 1-6, 2020.

GARCÍA, C. ; ESPINOZA, F.; CARREÓN, J. Model of intangible assets and capitals in organizations. International Journal of Research in Humanities and Social Studies, v. 5, n. 4, p. 1-12, 2018.

GARCÍA, C. et al. Contrast of a model of quality of life in students of the Autonomous University of the State of Mexico. Management Vision, v. 15, n. 1, p. 8-43, 2016.

GARCÍA, C. et al. Differences in reliability against risk, uncertainty and conflict between coffee farmers in Xilitla, Mexico. Eureka, v. 12, n. 1, p. 73-93, 2015.

GARCÍA, C.; CARREÓN, J.; HERNÁNDEZ, J.; RIVERA, B. L. Reliability and validity of an instrument that measures the sociopolitical dimension of quality of life. Pisucime, v. 5, n. 2, p. 79-92, 2015.

GARCÍA, C. et al. Contrast of a model of sociopolitical legitimacy. Trend \& Challenges, v. 20, n. 2, p. 121-133, 2015.

VILLEGAS, E. et al. Governance of intellectual capital millennials for the creation of intangible organizational values. Net Journal of Social Sciences, v. 6, n. 1, p. 1-9, 2018.

VILLEGAS, E. et al. Estructura factorial exploratoria del capital humano intelectual. Foro Educacional, v. 32, p. 31-51, 2019. 